\title{
Efektifitas antenatal perineal massage pada pasca persalinan (studi pada ibu hamil primigravida wilayah Kota Semarang)
}

\author{
Erna Kusumawati, ${ }^{*}$ Agustin Rahmawati, $^{2}$ \\ ${ }^{1,2}$ Program Studi DIII Kebidanan, Universitas Muhammadiyah Semarang, Indonesia
}

\begin{abstract}
Birth canal trauma is closely related to the birth process. It is also related to maternal morbidity and mortality. Nearly $90 \%$ of deliveries have perineal tears, either with or without an episiotomy. Antenatal Prineal Massage performed during the gestational period from 34 weeks can reduce the incidence of postpartum period. The purpose of this study was to see the effectiveness of giving antenatal perineal massage to postpartum including the length of perineal wound healing, Postpartum perineal pain, Postpartum sexual intercourse, Postpartum urine control mechanism, Postpartum stool control mechanism. The method used in achieving these goals uses a comparative or difference test with two different sample groups, namely pregnant women who are given perineal massage treatment as many as 45 people and the control group is pregnant women who are not given any treatment as many as 45 people. We use the approach method through the class of pregnant women in each region. This type of research is quasi-experimental with pretest-post-test control group design. The results of this study will be applied to every pregnant woman in the study area for the prevention of incidents/complications during childbirth due to perineal lacerations and post-delivery with the end being able to contribute to a decrease in maternal morbidity and mortality in the city of Semarang.
\end{abstract}

Keywords : effectiveness, perineal massage, post partum period

Trauma jalan lahir berhubungan erat dengan proses persalinan. Hal ini juga berhubungan dengan angka kesakitan dan kematian Ibu. Proses persalinan hampir $90 \%$ yang mengalami robekan perineum, baik dengan atau tanpa episiotomi. Antenatal Prineal Massage yang dilakukan pada periode kehamilan $\geq 34$ minggu dapat mengurangi terjadinya insiden yang terjadi pada pasca persalinan. Tujuan dilakukan penelitian ini adalah melihat efektifitas pemberian antenatal perineal massage terhadap pasca bersalin diantaranya lama penyembuhan luka perineum, Nyeri perineum pasca bersalin, Mekanisme kontrol urin pasca persalinan, Mekanisme kontrol faeces pasca persalinan. Metode yang dipakai dalam pencapaian tujuan tersebut menggunakan uji komparatif atau perbedaan dengan dua kelompok sampel yang berbeda yaitu ibu hamil yang diberikan perlakuan perineal massage sebanyak 45 orang dan kelompok kontrol adalah ibu hamil yang tidak diberikan perlakuan apapun sebanyak 45 orang. Kami menggunakan metode pendekatan melalui kelas ibu hamil di tiap wilayah. Jenis penelitian adalah kuasi eksperimental dengan pre test- post test control group design. Hasil penelitian ini akan diaplikasikan pada setiap ibu hamil di wilayah penelitian untuk pencegahan insiden/komplikasi saat persalinan akibat

\footnotetext{
"Corresponding Author: Erna Kusumawati (email: ernakusumawati@unimus.ac.id)
} 
laserasi perineum dan pasca persalinan dengan akhir mampu menyumbang penurunan angka kesakitan dan kematian Ibu di Kota Semarang.

Kata Kunci: efektifitas, perineal massage, pasca persalinan

\section{Pendahuluan}

Setiap tahun lebih dari 600.000 wanita meninggal akibat komplikasi pada periode kehamilan dan persalinan. Mayoritas hal tersebut terjadi di beberapa negara berkembang termasuk Indonesia. Perawatan antenatal, perinatal dan postnatal merupakan pelayanan pencegahan dasar untuk melindungi dan meningkatkan kesehatan ibu dan janin sampai tiba saat persalinannya. (Dönmez \& Kavlak, 2015)

Angka kematian di Kota Semarang hingga tahun 2016 adalah 17 kematian ibu, angka ini naik 2 poin dibandingkan di tahun 2018 sejumlah 15 kasus kematian ibu. Waktu kematian ibu terjadi pada masa bersalin 8,57\%; hamil $17,14 \%$ dan nifas $74,29 \%$. Penyebab kematian yaitu perdarahan 28\%, Ekalsia 34\%, Penyakit 26\% dan lain-lain termasuk infeksi 12\%. (Dinas Kesehatan Kota Semarang, 2016)

Penyebab kematian ibu perdarahan dan infeksi bisa dikarenakan terjadintya laserasi perineum pada proses persalinan. Sebagian besar wanita mengalami perlukaan jalan lahir akibat proses persalinan spontan, tekhnik episiotomi atau keduanya. Insiden perlukaan/laserasi jalan lahir kurang lebih $85 \%$ dari total persalinan pervaginam. Perlukaan jalan lahir sangat berhubungan erat dengan nyeri pasca persalinan. Faktor resiko yang berhubungan dengan perlukaan jalan lahir yang biasanya terjadi di perineum adalah jenis persalinan dan paritas. (Brick, 2012)

Perlukaan pada jalan lahir / perineum berefek pada kondisi fisik dan psikologis seorang wanita pasca persalinan. Wanita postpartum yang mempunyai luka perineum biasanya memiliki waktu penyembuhan yang relatif lebih lama dibandingkan dengan wanita postpartum yang tidak memiliki perlukaan jalan lahir. Efek yang terjadi antara lain nyeri, gangguan berkemih atau buang air besar, dan ketakutan untuk melakukan hubungan seksual pasca persalinan. (Kalichman, 2008)

Perineal massage atau pemijatan perineum merupakan salah satu cara untuk mempersiapkan perineum agar dapat meregang lebih mudah selama proses persalinan. Karena selama proses persalinan, peregangan jaringan perineum dibutuhkan untuk melahirkan kepala bayi hingga melewati introitus vagina. (Lecturer, 2014) 
Beberapa penelitian telah dilakukan beberapa tahun ini dalam hal tekhnik dan praktek pemecahan masalah persalinan, terutama perlukaan jalan lahir. Hasil yang didapatkan adalah perineal massage mempunyai efek positif dalam peregangan perineum dan mengurangi jumlah laserasi atau perlukaan jalan lahir. (Dönmez \& Kavlak, 2015)

\section{Metode}

Jenis penelitian adalah kuasi eksperimental dengan pre test-post test control group design. Dalam penelitian ini digunakan dua kelompok, kelompok perlakuan (A) dan kelompok kontrol (B). Kelompok perlakuan (A) dan kelompok kontrol (B), sama-sama dilakukan pre-test dan posttest. Hanya kelompok perlakuan (A) saja yang diberi intervensi / treatment.

\section{Hasil dan Pembahasan}

\section{Lama penyembuhan luka perinium}

Berdasarkan tabel pada kelompok perlakukan ratarata lama penyembuhan luka perineum adalah 6 hari. Pada kelompok kontrol rata-rata lama penyembuhan luka perineum adalah 7 hari.

Hasil uji Mann Whitney, diperoleh nilai $p$ $=0,100(p>0,05)$, dapat disimpulkan bahwa "tidak ada perbedaan bermakna antara lama penyembuhan luka perineum pada kelompok perlakuan dan kelompok kontrol pada akhir pengukuran".

Luka dapat sembuh melalui proses utama (primary intention) yang terjadi ketika tepi luka disatukan (approximated) dengan menjahitnya. Jika luka dijahit, terjadi penutupan jaringan yang disatukan dan tidak ada ruang yang kosong. Oleh karena itu, dibutuhkan jaringan granulasi yang minimal dan kontraksi sedikit berperan. Penyembuhan yang kedua yaitu melalui proses sekunder (secondary intention) terdapat defisit jaringan yang membutuhkan waktu yang lebih lama. (Boyle, 2009)

Penyembuhan luka perineum adalah mulai membaiknya luka perineum dengan terbentuknya jaringan baru yang menutupi luka perineum dalam jangka waktu 6-7 hari post partum. Kriteria penilaian luka adalah: 1) baik, jika luka kering,perineum menutup dan tidak ada tanda infeksi (merah, bengkak, panas, nyeri, fungsioleosa), 2) sedang, jika luka basah, perineum menutup, tidak ada tanda-tanda infeksi (merah, bengkak, panas, nyeri,fungsioleosa), 3) buruk, jika luka basah, perineum menutup/membuuka dan ada tanda-tanda infeksi merah,bengkak, panas, nyeri, 
fungsioleosa). (Darmawati, 2013)

Hasil penelitian menunjukkan tidak ada perbedaan yang signifikan lama penyembuhan luka perineum pada kelompok ibu hamil yang diberikan pijat perineum dan kelompok ibu hamil yang tidak dilakukan pemijatan perineum. Berdasarkan hasil penelitian sebelumnya yang dilakukan oleh Darmawati (2013), faktor yang mempengaruhi penyembuhan luka dengan lama penyembuhan luka perineum adalah faktor nutrisi ( $p$ value $0,012)$, faktor istirahat ( $p$ value 0,043$)$, faktor stress ( $p$ value 0,021), dan faktor infeksi ( $p$ value 0,000$)$.

\section{Nyeri Perinium Pasca Bersalin}

Skala nyeri pasca persalinan pada kelompok perlakukan didapatkan rata-rata nyeri yang dirasakan oleh responden pada skala 2-3 dimana interpretasinya adalah nyeri ringan atau sedikit sakit yang dirasakan selama pasca persalinan terutama dikarenakan luka bekas jahitan atau laserasi. Skala nyeri 3 yang nyata terasa namun dapat ditoleransi seperti mendapatkan pukulan dihidung . Pada kelompok kontrol didapatkan rata-rata nyeri yang dirasakan oleh responden pada skala 3 dimana interpretasinya adalah nyeri ringan. Dalam hal ini perbedaan intensitas nyeri pasca persalinan antara kelompok kasus dan kontrol tidak jauh berbeda.

Hasil uji Mann Whitney, diperoleh nilai $p=0,051(p>0,05)$, dapat disimpulkan bahwa "tidak ada perbedaan bermakna antara skala nyeri persalinan pada kelompok perlakuan dan kelompok kontrol pada akhir pengukuran".

Nyeri adalah kebutuhan fisiologis. Nyeri merupakan perasaan yang tidak nyaman yang sangat subyektif dan hanya orang yang mengalaminya yang dapat menjelaskan dan mengevaluasi perasaan tersebut. Nyeri jahitan perineum sebagai manifestasi dari luka bekas penjahitan yang dirasakan klien akibat ruptur perineum pada kala pengeluaran, yaitu bagian terdepan dari anak telah berada di dasar panggul.

\section{Mekanisme kontrol urin pasca persalinan}

Rata-rata mekanisme kontrol urin (BAK) pada kelompok perlakukan terjadi setelah 5-6 jam. Pada kelompok kontrol BAK terjadi setelah 6 jam. Dari hasil yang didapat tidak terdapat banyak selisih antara proses mekanisme pengeluaran/kontrol urin pasca bersalin. Hasil uji Mann Whitney, diperoleh nilai $p=0,116(p>0,05)$, dapat disimpulkan bahwa "tidak ada perbedaan 
bermakna antara mekanisme kontrol urin pasca persalinan pada kelompok perlakuan dan kelompok kontrol pada akhir pengukuran".

Hasil penelitian ini sesuai dengan penelitian Beckmann (2006) dimana tidak terdapat perbedaan antara kelompok yang diberikan perineal massage dengan kelompok yang tidak diberikan perineal massage pada mekanisme kontrol urin pasca persalinan.

\section{Mekanisme kontrol feses pasca persalinan}

Rata-rata mekanisme kontrol faeces (BAB) pada kelompok perlakukan terjadi setelah 1-2hari. Pada kelompok kontrol BAB terjadi setelah 2 hari Dari hasil yang didapat tidak terdapat banyak selisih antara proses mekanisme pengeluaran/kontrol BAB pasca bersalin.

Hasil uji Mann Whitney, diperoleh nilai $p=0,302(p>0,05)$, dapat disimpulkan bahwa "tidak ada perbedaan bermakna antara mekanisme kontrol faeces pasca persalinan pada kelompok perlakuan dan kelompok kontrol pada akhir pengukuran".

Hasil penelitian ini sesuai dengan penelitian Beckmann (2006) dimana tidak terdapat perbedaan antara kelompok yang diberikan perineal massage dengan kelompok yang tidak diberikan perineal massage pada mekanisme kontrol faeces pasca persalinan.

\section{Kesimpulan}

1. Rata-rata lama penyembuhan luka perineum adalah 6 hari. Pada kelompok kontrol rata-rata lama penyembuhan luka perineum adalah 7 hari.

2. Skala nyeri pasca persalinan pada kelompok perlakukan didapatkan ratarata nyeri yang dirasakan oleh responden pada skala 2-3 dimana interpretasinya adalah nyeri ringan atau sedikit sakit yang dirasakan selama pasca persalinan

3. Rata-rata mekanisme kontrol urin (BAK) pada kelompok perlakukan terjadi setelah 5-6 jam. Pada kelompok kontrol BAK terjadi setelah 6 jam. Dari hasil yang didapat tidak terdapat banyak selisih antara proses mekanisme pengeluaran/kontrol urin pasca bersalin.

4. Rata-rata mekanisme kontrol faeces (BAB) pada kelompok perlakukan terjadi setelah 1-2hari. Pada kelompok kontrol BAB terjadi setelah 2 hari Dari 
hasil yang didapat tidak terdapat

banyak selisih antara proses

mekanisme pengeluaran / kontrol BAB

pasca bersalin.

\section{Daftar Pustaka}

Boyle, M. (2009). Penyembuhan Luka. EGC.

Brick, D. D. (2012). Evidence based guidelines for midwifery-led care in labour: Care of the perineum. Royal College of Midwives, 9.

Darmawati, I. S. (2013). Hubungan Faktor-Faktor Yang Mempengaruhi Penyembuhan Luka Dengan Lama Penyembuhan Luka Perineum Ibu Nifas. Idea Nursing Journal, 4(3), 41-51.
Dinas Kesehatan Kota Semarang. (2016). Profil Kesehatan Kota Semarang Tahun 2016. Dinas Kesehatan Kota Semarang, 72.

Dönmez, S., \& Kavlak, O. (2015). Effects of Prenatal Perineal Massage and Kegel Exercises on the Integrity of Postnatal Perine. Health, 07(04), 495-505. https://doi.org/10.4236/health.2015.74059

Kalichman, L. (2008). Perineal massage to prevent perineal trauma in childbirth. Israel Medical Association Journal, 10(7), 531-533.

Lecturer, M. (2014). Antenatal Perineal Massage. NHS Turst, 7(1), 2-6. http://www.ouh.nhs.uk/patientguide/leaflets/files/10938Pmassage.pdf 